\title{
Pengaruh Motivasi dan Lingkungan Kerja Terhadap Kinerja Karyawan Bagian Packing Produk Minuman PT. Singa Mas Pandaan
}

\author{
Muhammad Afif \\ Program Studi Manajemen, STIE Kertanegara Malang \\ e-mail: afifm0101@gmail.com
}

\begin{abstract}
This study aims to determine the influence of motivation and work environment influence simultaneously and partially and to know which variables that influence dominant between motivation variables and work environment on employee performance of packing beverage products at PT. Lion Mas Pandaan. In this study the primary data obtained through survey results of questionnaires distributed to the study respondents amounted to 32 respondents. In this study used data analysis that is with the test of validity, reliability, multiple linear regression test, simultaneous test and partial test to find out how big influence of each independent variable to the dependent variable. The results of this study proves that based on simultaneous calculation results there is a mutual influence of independent variables that are positive and significant to employee performance variables. While the test results in multiple linear regression and partially showed that each of the independent variables are motivation and work environment have a positive and significant effect on the dependent variable that is the employee's performance at PT. Lion Mas Pandaan.
\end{abstract}

Keywords: Motivation, work environment, employee performance

\begin{abstract}
Abstrak
Penelitian ini bertujuan untuk mengetahui pengaruh motivasi dan lingkungan kerja berpengaruh secara simultan maupun parsial dan untuk mengetahui variabel mana yang berpengaruh dominan antara variabel motivasi dan lingkungan kerja terhadap kinerja karyawan bagian packing produk minuman pada PT. Singa Mas Pandaan. Dalam penelitian ini data primer yang diperoleh melalui survei hasil kuesioner yang disebar kepada responden penelitian berjumlah 32 responden. Dalam penelitian ini digunakan analisis data yaitu dengan uji validitas, reliabilitas, uji regresi linier berganda, uji simultan dan uji parsial untuk mengetahui seberapa besar pengaruh dari masing-masing variabel bebas terhadap variabel terikat. Hasil penelitian ini membuktikan bahwa berdasarkan hasil perhitungan secara simultan terdapat pengaruh secara bersama-sama dari variabel bebas yang bernilai positif dan signifikan terhadap variabel kinerja karyawan. Sedangkan hasil uji secara regresi linier berganda dan secara parsial menujukkan bahwa masing-masing dari varibael bebas yaitu motivasi dan lingkungan kerja berpengaruh positif dan signifikan terhadap variabel terikat yaitu kinerja karyawan pada PT. Singa Mas Pandaan.
\end{abstract}

Kata kunci: Motivasi, lingkungan kerja, kinerja karyawan 


\section{I.PENDAHULUAN}

Pada perkembangan globalisasi sekarang ini perusahaan dituntut untuk dapat memaksimalkan kinerja karyawan. Sumber daya manusia memiliki peran penting dalam suatu perusahaan dari segala aspek yang berkaitan dengan sumber daya manusia serta memiliki kontribusi besar dalam kegiatan perusahaan. Permasalahan dalam suatu perusahaan terkait dengan sumber daya manusia adalah bagaimana menciptakan sumber daya manusia yang berkualitas. Dalam hal ini, perusahaan perlu mengelola sumber daya manusia sebaik mungkin, karena kunci sukses untuk mencapai tujuan suatu perusahaan bukan hanya pada keunggulan teknologi dan tersedianya dana, tetapi juga dari sektor manusianya. Menurut Mangkunegara (2013:67) kinerja adalah hasil kerja baik secara kualitas dan kuantitas yang dicapai oleh seseorang dalam melaksanakan tugas sesuai tanggung jawab yang diberikan. Dengan adanya kinerja yang tinggi, diharapkan tujuan perusahaan dapat tercapai, sebaliknya tujuan organisasi tidak tercapai bila karyawan bekerja tidak memiliki kinerja yang baik.

Menurut Widodo (2015:187) motivasi adalah kekuatan yang ada dalam seseorang yang mendorong perilakunya untuk melakukan tindakan. Besarnya intensitas kekuatan dari dalam diri seseorang untuk melakukan suatu tugas atau mencapai sasaran memperlihatkan sejauh mana tingkat motivasinya. Untuk meningkatkan dan mempertahankan motivasi memerlukan perjuangan bagi para pemimpin dan anggotanya. Menurut Sedarmayati (2013:23) lingkungan kerja adalah suatu tempat yang terdapat sejumlah kelompok dimana di dalamnya terdapat beberapa fasilitas pendukung untuk mencapai tujuan perusahaan sesuai dengan visi dan misi perusahaan. Dari teoritis di atas dapat disimpulkan bahwa lingkungan kerja dalam suatu perusahaan termasuk salah satu hal yang penting untuk diperhatikan. Meskipun lingkungan kerja tidak melaksanakan proses produksi dalam suatu perusahaan, namun lingkungan kerja mempunyai pengaruh langsung terhadap para karyawan yang melaksanakan proses produksi tersebut. Lingkungan kerja yang memusatkan bagi karyawannya dapat meningkatkan kinerja. Sebaliknya lingkungan kerja yang tidak memadai dapat menurunkan kinerja dan akhirnya dapat menurunkan motivasi kerja karyawan.

\section{A. Rumusan Masalah}

Berdasarkan latar belakang masalah yang telah dipaparkan di atas, dapat dirumuskan masalah sebagai berikut:

1. Apakah motivasi dan lingkungan kerja berpengaruh secara simultan terhadap kinerja karyawan bagian packing produk minuman pada PT. Singa Mas Pandaan?

2. Apakah motivasi dan lingkungan kerja berpengaruh secara parsial terhadap kinerja karyawan bagian packing produk minuman pada PT. Singa Mas Pandaan?

3. Manakah diantara motivasi dan lingkungan kerja berpengaruh paling dominan terhadap kinerja karyawan bagian packing produk minuman pada PT. Singa Mas Pandaan? 


\section{B. Tujuan Penelitian}

Berdasarkan latar belakang dan rumusan masalah yang ada, maka penelitian ini dilakukan dengan tujuan:

1. Untuk mengetahui pengaruh motivasi dan lingkungan kerja berpengaruh secara simultan terhadap kinerja karyawan bagian packing produk minuman pada PT. Singa Mas Pandaan.

2. Untuk mengetahui pengaruh motivasi dan lingkungan kerja berpengaruh secara parsial terhadap kinerja karyawan bagian packing produk minuman pada PT. Singa Mas Pandaan.

3. Untuk mengetahui manakah diantara motivasi dan lingkungan kerja berpengaruh paling dominan terhadap kinerja karyawan bagian packing produk minuman pada PT. Singa Mas Pandaan?

\section{METODE}

\section{A. Rancangan Penelitian}

Metode penelitian yang digunakan oleh peneliti menggunakan metode penelitian deskriptif kuantitatif. Menurut Sugiyono (2014:238) statistik deskriptif adalah statistik yang digunakan untuk menganalisis data dengan cara mendeskripsikan atau menggambarkan data yang yang telah terkumpul sebagaimana adanya tanpa bermaksud membuat kesimpulan yang berlaku untuk umum atau generalisasi.

Metode penelitian kuantitatif adalah metode penelitian yang berlandaskan pada filsafat positifisme, digunakan untuk meneliti pada populasi atau sampel tertentu, pengumpulan data menggunakan instrumen penelitian, analisis data bersifat kuantitatif atau statistik, dengan tujuan untuk menguji hipotesis yang telah ditetapkan (Sugiyono, 2014:35).

\section{B. Ruang Lingkup Penelitian}

Suatu masalah penelitian yang dibahas dan agar tidak terjadi pembahasan yang meluas, maka peneliti membuat suatu batasan masalah pada penelitian ini, yaitu pada variabel bebas motivasi sebagai X1 dan lingkungan kerja sebagai X2. Sedangkan variabel terikat kinerja karyawan sebagai $Y$.

\section{Lokasi dan Waktu Penelitian}

1. Lokasi Penelitian

PT. Singa Mas yang bertempat di Dusun Rajeg, Sumber Gedang, Kecamatan Pandaan, Kabupaten Pasuruan Jawa Timur.

2. Waktu Penelitian

Waktu penelitian ini dilaksanakan pada objek penelitian yaitu di PT. Singa Mas pada bulan Desember 2017 sampai Januari 2018. 


\section{Jenis dan Sumber Data}

1. Jenis Data

Jenis data penelitian ini adalah kuantitatif. Menurut Sugiyono (2017:8) penelitian kuantitatif adalah metode penelitian yang berlandaskan pada filsafat positifisme, digunakan untuk meneliti pada populasi atau sampel tertentu, pengumpulan data menggunakan instrumen penelitian, analisis data bersifat kuantitatif atau statistik, dengan tujuan untuk menguji hipotesis yang telah ditetapkan.

2. Sumber Data

a)

Data

Primer

Menurut Sugiyono (2012:139) menjelaskan sumber primer adalah sumber data yang langsung memberikan data kepada pengumpul data. Pengumpulan data primer dalam penelitian ini melalui cara menyebarkan kuesioner secara langsung dengan menggunakan daftar pernyataan yang diedarkan kepada responden yaitu kepada pihak-pihak yang berhubungan dengan penelitian yang dilakukan.

Data primer penelitian ini yaitu mengacu pada indikator-indikator variabel penelitian yaitu motivasi (X1), lingkungan kerja (X2) dan kinerja karyawan $(\mathrm{Y})$.

b)

Data

Sekunder

Menurut Sugiyono (2012:141) mendefinisikan data sumber sekunder adalah sumber data yang diperoleh dengan cara membaca, mempelajari dan memahami melalui media lain yang bersumber dari literatur, buku-buku. Data sekunder diperoleh dari dokumen perusahaan meliputi struktur organisasi, data personalia dan gambaran umum perusahaan.

\section{E. Instrumen Penelitian}

Instrumen penelitian merupakan suatu alat yang digunakan untuk mengukur fenomena alam maupun sosial yang diamati (Sugiyono, 2009:102). Instrumen penelitian yang digunakan dalam penelitian ini adalah angket atau kuesioner (questionnaires). Skala pengukuran merupakan kesepakatan yang digunakan sebagai acuan untuk menentukan panjang pendeknya interval yang ada dalam alat ukur, sehingga alat ukur tersebut bila digunakan dalam pengukuran akan menghasilkan data kuantitatif. Dalam penelitian ini, penulis menggunakan skala likert. 
Menurut Sugiyono (2014:132) skala likert yaitu skala yang digunakan untuk mengukur sikap, pendapat, dan persepsi seseorang atau sekelompok orang tentang fenomena sosial.

Menurut Sugiyono (2014:133), “Jawaban setiap instrumen yang menggunakan skala likert mempunyai gradasi dari sangat positif sampai sangat negatif, yang dapat berupa kata-kata kemudian diberi skor, yaitu:

Tabel 1. Skala Berdasarkan Skala Likert

\begin{tabular}{|l|c|}
\hline \multicolumn{1}{|c|}{ Pernyataan } & Skor \\
\hline Sangat Setuju & 5 \\
\hline Setuju & 4 \\
\hline Netral & 3 \\
\hline Tidak Setuju & 2 \\
\hline Sangat Tidak Setuju & 1 \\
\hline
\end{tabular}

Sumber : Sugiyono (2014:133)

Mengacu pada ketentuan tersebut, instrumen penelitian yang menggunakan likert dapat dibuat dalam bentuk pengisian skor pada kolom kuesioner dan dapat dihitung skornya, kemudian ditabulasikan untuk menguji validitas dan reliabilitas data.

\section{Uji Validitas}

Suatu instrumen dinyatakan valid apabila mampu mengukur apa yang diinginkan dan dapat mengungkapkan data dari variabel yang diteliti secara tepat. Pengujian validitas adalah pengujian yang ditujukan untuk mengetahui suatu data dapat dipercaya kebenarannya sesuai dengan kenyataan. Sugiyono (2014:121) menyatakan bahwa instrumen yang valid berarti alat ukur yang digunakan untuk mendapatkan data (mengukur) itu valid. Valid berarti instrumen tersebut dapat digunakan untuk mengukur apa yang seharusnya diukur.

Instrumen yang valid berarti alat ukur yang digunakan untuk mendapatkan data (mengukur) itu valid. Uji validitas instrumen yang digunakan adalah validitas isi dengan analisis item, yaitu dilakukan dengan menghitung korelasi antara skor butir instrumen dengan skor total. Kriteria pengambilan keputusan valid tidaknya suatu kuesioner menurut Sugiono (2003:13) adalah:

1) Kalau $r$ hitung $>r$ tabel maka kuesioner tersebut dinyatakan valid.

2) Kalau $r$ hitung $<r$ tabel maka kuesioner tersebut tidak valid 
Metode yang digunakan untuk mengukur validitas data adalah dengan melihat nilai Corrected Item Total Correlation sebagai $r$ hitung pada perhitungan menggunakan program statisik (SPSS).

\section{Uji Reliabilitas}

Pengujian ini bertujuan untuk mengukur sejauh mana konsistensi dari suatu instrumen penelitian. Suatu kuesioner dikatakan reliabel, apabila jawaban responden terhadap pertanyaan tersebut konsisten dari waktu ke waktu. Hasil uji ini akan dinyatakan dalam koefisien alpha, yang berkisar antara angka 0 s.d 1 . Semakin mendekati 1 sebuah alat ukur dikatakan semakin reliabel dan sebaliknya.

Menurut Sekaran (2000) Membagi tingkatan reliabilitas dengan kriteria melihat nilai cronbach alpha lebih besar dari 0,60. Dengan kriteteria tingkatan reliabilitas sebagai berikut:

1) Jika nilai alpha atau r hitung 0,8-1,0 maka dikatakan reliabilitas baik.

2) Jika nilai alpha atau $r$ hitung 0,6 - 0,799 maka dikatakan reliabilitas diterima.

3) Jika nilai alpha atau $r$ hitung kurang dari 0,6 maka dikatakan reliabilitas kurang baik.

\section{F. Populasi dan Teknik Pengambilan Sampel}

\section{Populasi}

Berdasarkan pada judul penelitian maka penulis menentukan populasi. Menurut Sugiyono (2014:115) bahwa populasi adalah wilayah generalisasi yang terdiri atas obyek/subyek yang mempunyai kualitas dan karakteristik tertentu yang diterapkan oleh peneliti untuk dipelajari dan kemudian ditarik kesimpulannya.

Populasi pada penelitian ini adalah karyawan bagian packing produk minuman di PT. Singa Mas Pandaan yang berjumlah 32 karyawan.

\section{Teknik Pengambilan Sampel}

Dalam penelitian ini peneliti menggunakan metode probability sampling, sedangkan cara pengambilan sampel yang digunakan adalah sampling jenuh. Menurut Sugiyono (2013:118) yang dimaksud Probability sampling adalah teknik pengambilan sampel yang memberikan peluang yang sama bagi setiap unsur (anggota) populasi untuk dipilih menjadi anggota sampel. Adapun untuk metode pengambilan sampling jenuh adalah teknik penentuan sampel bila semua anggota populasi digunakan sebagai sampel (Sugiyono, 2011:68). 
Berdasarkan penjelasan di atas maka dari jumlah seluruh karyawan bagian packing produk minuman PT. Singa Mas Pandaan sebanyak 32 karyawan adalah sebagai sampel penelitian ini. Alasan peneliti menggunakan sampel tersebut adalah status peneliti masih menjadi karyawan PT. Singa Mas Pandaan bagian packing produk minuman, maka dari itu peneliti menggunakan sampel penelitian tempat peneliti bekerja agar mempermudah mendapatkan data penelitian agar lebih akurat.

\section{G. Teknik Pengumpulan Data}

Teknik pengumpulan data merupakan cara mengumpulkan data yang dibutuhkan untuk menjawab rumusan masalah penelitian. Dalam penelitian ini teknik pengumpulan data yaitu dengan survei langsung ditempat peneliti yaitu di PT. Singa Mas Pandaan bagian packing produk minuman. Adapun teknik pengumpulan data yang digunakan dalam penelitian ini adalah kuesioner. Kuesioner merupakan intrumen penelitian yang bertujuan untuk mengukur variabel (Noor, 2014:15).

\section{H. Analisis Data}

\section{Regresi Linier Berganda}

Menurut Danang Sunyoto (2016:47) menyatakan tujuan analisis regresi untuk mengetahui besarnya pengaruh variabel

bebas $(X)$ terhadap variabel terikat $(Y)$. Untuk mengetahui pengaruh masingmasing variabel independen yaitu motivasi (X1), dan lingkungan kerja (X2) terhadap variabel dependen yaitu kinerja karyawan $(\mathrm{Y})$.

Analisis regresi linier berganda (Sugiyono, $2010: 276$ ) dapat dirumuskan sebagai berikut:

$$
Y=b+b 1 X 1+b 2 X 2+e
$$

Keterangan:

Y $\quad$ = kinerja karyawan

b $\quad=$ bilangan konstanta

$\mathrm{b} 1, \mathrm{~b} 2=$ koefisien regresi

$\mathrm{X} 1=$ motivasi

X2 = lingkungan kerja

e $\quad=$ epsilon (pengaruh faktor lain)

\section{Uji Asumsi Klasik}

Uji asumsi klasik merupakan pengujian yang bertujuan untuk memastikan bahwa data yang diperoleh dapat dianalisis dengan metode analisis regresi. Uji asumsi klasik terdiri dari uji normalitas, uji multikoleniaritas dan uji heteroskedatisitas.

a) Uji Normalitas 
Uji normalitas bertujuan untuk mengetahui apakah variabel penelitian memiliki distribusi normal atau tidak. Uji normalitas dalam penelitian ini dilaksanakan dengan menggunakan analisis grafik. Analisis grafik yang andal untuk menguji normalitas data adalah dengan melihat histogram dan normal probability plot. Histogram merupakan grafik yang membandingkan data observasi dengan distribusi yang mendekati normal. Sedangkan normal probability plot membandingkan distribusi kumulatif dari distribusi normal. Kriteria pengambilan keputusan dalam pengujian normalitas menggunakan probability plot, menurut Ghozali (2016:156) adalah jika titik menyebar di sekitar garis diagonal dan mengikuti arah garis diagonal maka pola distribusi dikatakan normal sehingga model regresi memenuhi asumsi normalitas. Sebaliknya, jika titik menyebar jauh dari garis diagonal dan tidak mengikuti arah garis diagonal, maka pola distribusi tidak normal sehingga model regresi tidak memenuhi asumsi normalitas

b) Uji Multikolinieritas

Uji multikolinieritas bertujuan untuk mengetahui apakah ada korelasi diantara variabel bebas (independen). Jika antar variabel independen saling berkorelasi maka variabel ini tidak ortogonal sehingga tidak bisa di uji menggunakan model regresi. Untuk mengetahui ada tidaknya multikolinearitas di antara variabel independen dapat dilihat dari nilai toleran maupun varian inflation factor (VIF). Kriteria pengambilan keputusan penggunaan nilai toleran dan VIF tersebut menurut Ghozali (2016:104) adalah jika nilai toleran $>0,10$ atau nilai VIF $<10$ maka tidak ada multikoleniaritas di antara variabel independen. Sebaliknya, jika nilai toleran $\leq 0,10$ atau nilai VIF $\geq 10$ maka ada multikoleniaritas di antara variabel independen.

c) Uji Heteroskedastisitas

Uji heteroskedastisitas bertujuan mengetahui apakah dalam model regresi terjadi ketidaksamaan varian dari residual satu pengamatan ke pengamatan yang lain. Jika varian dari residual satu pengamatan ke pengamatan lain sama, maka disebut homoskedastisitas. Sebaliknya, jika varian dari residual satu pengamatan ke pengamatan lain tidak sama maka disebut heteroskedastisitas. Model regresi yang baik adalah yang homoskedastisitas atau tidak terjadi heteroskedastisitas.

Pengujian heteroskedastisitas dalam penelitian ini dilakukan dengan melihat grafik plot antara prediksi nilai variabel terikat dengan residualnya. Kriteria pengambilan keputusan dalam pengujian ini menurut Ghozali (2016:134) adalah jika ada pola tertentu, seperti titik-titik yang ada membentuk pola tertentu yang teratur (bergelombang, melebar kemudian menyempit) maka telah terjadi 
heteroskedastisitas. Sebaliknya, jika tidak ada pola yang jelas serta titiktitik menyebar di atas dan di bawah angka 0 pada sumbu $Y$ maka tidak terjadi heteroskedastisitas.

d) Uji Autokorelasi

Persamaan regresi yang baik adalah yang tidak memiliki masalah autokorelasi, jika terjadi autokorelasi maka persamaan tersebut menjadi tidak baik atau tidak layak dipakai prediksi. Masalah autokorelasi baru timbul jika ada kolerasi secara linier antara kesalahan pengganggu periode $t$ (berada) dengan kesalahan pengganggu periode $t-1$

(sebelumnya). Dengan demikian dapat dikatakan bahwa uji asumsi klasik autokorelasi dilakukan untuk data time series atau data yang mempunyai seri waktu, misalnya data dari tahun 2000 s/d 2012 (Danang Sunyoto, 2016:97).

Menurut Danang Sunyoto (2016:98) salah satu ukuran dalam menentukan ada tidaknya masalah autokorelasi dengan uji DurbinWatson (DW) dengan ketentuan sebagai berikut:

a) "Terjadi autokorelasi positif, jika nilai DW dibawah -2 (DW $<-2)$.

b) Tidak terjadi autokorelasi, jika nilai DW berada di antara -2 dan +2 atau $-2<$ DW $<+2$.

c) Terjadi autokorelasi negatif jika DW di atas +2 atau DW $>+2$ ".

\section{Pengujian Hipotesis}

A. Uji Pengaruh Simultan (Uji F)

Menurut Ghozali (2012: 98) Uji Statistik F pada dasarnya menunjukkan apakah semua variabel independen atau variabel bebas yang dimasukkan dalam model mempunyai pengaruh secara bersamasama terhadap variabel dependen atau variabel terikat

Untuk menguji apakah masing-masing variabel bebas berpengaruh secara signifikan terhadap variabel terikat secara bersamasama dengan $\alpha=0,05$.

Maka cara yang dilakukan adalah:

a) Bila (P-Value) $<0,05$ artinya variabel independen secara simultan mempengaruhi variabel dependen.

b) Bila ( $\mathrm{P}$-Value) $>0,05$ artinya variabel independen secara simultan tidak mempengaruhi variabel dependen.

Berdasarkan penjelasan diatas nilai $P$-Value yaitu nilai probability atau signifikansi penelitian. Nilai Probabilitas ( $P$-Value) dapat diartikan sebagai besarnya peluang (probabilitas) yang diamati dari statistik uji. Sedangkan P-Value atau Sig. adalah nilai kesalahan yang didapat peneliti dari hasil perhitungan statistik. 


\section{B. Uji Pengaruh Parsial ( Uji t)}

Menurut Ghozali (2012: 98) Uji beda t-test digunakan untuk menguji seberapa jauh pengaruh variabel independen yang digunakan dalam penelitian ini secara individual dalam menerangkan variabel dependen secara parsial.

Sedangkan menurut Sugiyono (2011:194) uji t digunakan untuk mengetahui masing-masing sumbangan variabel bebas secara parsial terhadap variabel terikat, menggunakan uji masing-masing koefisien regresi variabel bebas apakah mempunyai pengaruh yang bermakna atau tidak terhadap variabel terikat. Untuk menguji apakah masing-masing variabel bebas berpengaruh secara signifikan terhadap variabel terikat secara parsial dengan $\alpha=0,05$.

Maka cara yang dilakukan adalah:

a) Bila (P-Value) $<0,05$ artinya variabel independen secara parsial mempengaruhi variabel dependen.

b) Bila (P-Value) $>0,05$ artinya variabel independen secara parsial tidak mempengaruhi variabel dependen.

Berdasarkan penjelasan di atas nilai P-Value dapat diartikan sebagai besarnya peluang (probabilitas) yang diamati dari statistik uji. Nilai $\alpha$ (alpha) adalah kesalahan maksimal yang ditentukan oleh peneliti, Sedangkan $P$-Value atau Sig. adalah nilai kesalahan yang didapat peneliti dari hasil perhitungan statistik. Maka jika nilai $P$-Value variabel motivasi dan lingkungan kerja lebih besar dari nilai $\alpha$ (alpha) maka dinyatakan tidak ada pengaruh yang signifikan terhadap variabel terikat. Sebaliknya, jika nilai $P$-Value variabel motivasi dan lingkungan kerja lebih kecil dari nilai a (alpha) maka dinyatakan ada pengaruh yang signifikan terhadap variabel kinerja karyawan.

\section{HASIL DAN PEMBAHASAN}

\section{A. Analisis Data}

1) Hasil Uji Validitas

a. Uji validitas digunakan untuk mengukur sah atau valid tidaknya sesuatu kuesioner. Uji signifikan dilakukan dengan membandingkan nilai $r$ hitung dengan nilai $r$ tabel. Jika $r$ tiap butir lebih besar dari $r$ dan nilai $r$ positif, maka butir atau pertanyaan tersebut dikatakan valid. Pengujian menggunakan uji dua sisi dengan taraf signifikansi 0,05 dan hasil dibandingkan dengan $r$ tabel product moment dengan $N$ (jumlah responden) -2 .

b. Uji validitas peneliti mengajukan 15 pernyataan kuesioner yang mengacu pada indikator-indikator variabel penelitian yaitu motivasi, lingkungan kerja dan kinerja karyawan kemudian peneliti sebarkan kepada sampel penelitian yaitu sebanyak 32 responden. 
c. Setelah dilakukan perhitungan menggunakan program SPSS 20.0 (Statistical Packages for the Social Sciences), berikut hasil perhitungan:

Tabel 2. Hasil Perhitungan Item-Total Statistics

\begin{tabular}{|l|r|r|r|r|}
\hline \multicolumn{1}{|c|}{ Instrumen } & $\begin{array}{r}\text { Scale Mean if } \\
\text { Item Deleted }\end{array}$ & $\begin{array}{r}\text { Scale Variance } \\
\text { if Item Deleted }\end{array}$ & $\begin{array}{c}\text { Corrected } \\
\text { Item-Total } \\
\text { Correlation }\end{array}$ & $\begin{array}{c}\text { Cronbach's } \\
\text { Alpha if Item } \\
\text { Deleted }\end{array}$ \\
\hline Motivasi1 & 58,34 & 73,459 &, 822 &, 916 \\
Motivasi2 & 58,34 & 74,297 &, 675 &, 921 \\
Motivasi3 & 58,38 & 74,758 &, 729 &, 919 \\
Motivasi4 & 57,94 & 81,415 &, 579 &, 924 \\
Motivasi5 & 58,28 & 79,564 &, 473 &, 927 \\
Lingkungan kerja1 & 57,91 & 77,959 &, 651 &, 921 \\
Lingkungan kerja2 & 58,28 & 76,080 &, 821 &, 917 \\
Lingkungan kerja3 & 58,28 & 82,402 &, 423 &, 927 \\
Lingkungan kerja4 & 57,97 & 81,451 &, 636 &, 923 \\
Lingkungan kerja5 & 57,91 & 81,314 &, 638 &, 923 \\
Kinerja Karyawan1 & 58,28 & 73,112 &, 913 &, 913 \\
Kinerja Karyawan2 & 58,38 & 75,597 &, 613 &, 923 \\
Kinerja Karyawan3 & 58,34 & 75,072 &, 697 &, 920 \\
Kinerja Karyawan4 & 57,94 & 81,415 &, 617 &, 922 \\
Kinerja Karyawan5 & 58,25 & 78,710 & \\
\hline
\end{tabular}

Sumber: Hasil perhitungan SPSS tahun 2018

Dari hasil uji validitas pada tabel di atas menunjukkan bahwa pada kolom Corrected Item-total Correlation, merupakan korelasi antar skor butir instrumen dengan skor total item yang dapat digunakan untuk menguji validitas. Nilai pada kolom Corrected Item-total Correlation merupakan nilai $r$ hitung yang akan dibandingkan dengan $r$ tabel untuk mengetahui validitas pada tiap butir instrumen kuesioner.

Kesimpulan dari tabel hasil perhitungan uji validitas di atas bahwa nilai $r$ hitung pada kolom Corrected Item-total Correlation masing-masing item pertanyaan lebih besar 
dari nilai $r$ tabel pada signifikansi 5\% dengan jumlah sampel penelitian 32 responden yaitu sebesar 0,349. Maka dapat disimpulkan bahwa nilai $r$ hitung dari setiap butir instrumen kuesioner dinyatakan valid.

Sehubungan dengan uji validitas di atas peneliti memberikan keputusan valid tiap instrumen yang mengacu pada indikator penelitian yang telah dibahas pada bab sebelumnya, dapat dilihat pada tabel berikut:

\section{Tabel 3. Hasil Uji Validitas Tiap Butir Instrumen}

\begin{tabular}{|c|c|c|c|c|}
\hline No & Instrumen & r hitung & $r$ tabel & Ket. \\
\hline \multicolumn{5}{|c|}{ Motivasi (X1) } \\
\hline $\begin{array}{l}\text { Butir } \\
1\end{array}$ & $\begin{array}{l}\text { PT. Singa Mas Pandaan telah memberikan gaji pokok } \\
\text { sesuai peraturan undang-undang yang berlaku. }\end{array}$ & 0,822 & 0,349 & Valid \\
\hline Butir & PT. Singa Mas Pandaan memberikan bonus kepada & & & \\
\hline 2 & $\begin{array}{l}\text { karyawan yang memiliki jam kerja aktif tambahan dan } \\
\text { berprestasi dalam bekerja. }\end{array}$ & 0,675 & 0,349 & Valid \\
\hline $\begin{array}{l}\text { Butir } \\
3\end{array}$ & $\begin{array}{l}\text { PT. Singa Mas Pandaan memberikan jaminan kesehatan } \\
\text { kepada setiap karyawan dan memberikan pesangon jika } \\
\text { berhenti bekerja dengan syarat yang telah ditentukan oleh } \\
\text { perusahaan. }\end{array}$ & 0,729 & 0,349 & Valid \\
\hline $\begin{array}{l}\text { Butir } \\
4\end{array}$ & $\begin{array}{l}\text { Sebagai karyawan PT. Singa Mas Pandaan kami memiliki } \\
\text { rasa aman saat melakukan proses kerja. }\end{array}$ & 0,579 & 0,349 & Valid \\
\hline $\begin{array}{l}\text { Butir } \\
5\end{array}$ & $\begin{array}{l}\text { PT. Singa Mas Pandaan memberikan promosi karir berupa } \\
\text { pengembangan dan peningkatan bagi tiap karyawan } \\
\text { dalam waktu yang lama bahkan sampai pensiun. }\end{array}$ & 0,473 & 0,349 & Valid \\
\hline \multicolumn{5}{|c|}{ Lingkungan Kerja (X2) } \\
\hline $\begin{array}{l}\text { Butir } \\
6\end{array}$ & $\begin{array}{l}\text { PT. Singa Mas Pandaan telah merancang sistem } \\
\text { penerangan di tempat kerja, sehingga karyawan dapat } \\
\text { melakukan proses produksi dengan maksimal. }\end{array}$ & 0,651 & 0,349 & Valid \\
\hline $\begin{array}{l}\text { Butir } \\
7\end{array}$ & $\begin{array}{l}\text { PT. Singa Mas Pandaan telah merancang sirkulasi udara } \\
\text { dengan memberikan tanaman disekitar di tempat kerja, } \\
\text { sehingga kadar udara kotor dapat berkurang dan } \\
\text { menciptakan suasana sejuk ditempat kerja. }\end{array}$ & 0,821 & 0,349 & Valid \\
\hline $\begin{array}{l}\text { Butir } \\
8\end{array}$ & $\begin{array}{l}\text { PT. Singa Mas Pandaan telah mengatasi kebisingan di } \\
\text { tempat kerja, sehingga karyawan dapat melakukan tugas } \\
\text { produksi dengan nyaman tidak terganggu oleh kebisingan }\end{array}$ & 0,423 & 0,349 & Valid \\
\hline
\end{tabular}




\begin{tabular}{|c|c|c|c|c|}
\hline $\begin{array}{l}\text { Butir } \\
9\end{array}$ & $\begin{array}{l}\text { PT. Singa Mas Pandaan telah mengatasi bau tidak sedap } \\
\text { terutama dengan limba pabrik yang dianggap sebagai } \\
\text { pencemaran. }\end{array}$ & 0,636 & 0,349 & Valid \\
\hline $\begin{array}{l}\text { Butir } \\
10\end{array}$ & $\begin{array}{l}\text { PT. Singa Mas Pandaan memberikan jaminan keamanan } \\
\text { dengan menempatkan petugas di setiap sektor kerja di } \\
\text { lingkungan perusahaan. }\end{array}$ & 0,638 & 0,349 & Valid \\
\hline \multicolumn{5}{|c|}{ Kinerja Karyawan (Y) } \\
\hline $\begin{array}{l}\text { Butir } \\
11\end{array}$ & $\begin{array}{l}\text { Sebagai karyawan PT. Singa Mas Pandaan kami } \\
\text { memberikan kualitas kerja yang maksimal sehingga dapat } \\
\text { memenuhi tujuan perusahaan. }\end{array}$ & 0,913 & 0,349 & Valid \\
\hline $\begin{array}{l}\text { Butir } \\
12\end{array}$ & $\begin{array}{l}\text { Sebagai karyawan PT. Singa Mas Pandaan terus berusaha } \\
\text { menyelesaikan tiap tugas yang diberikan terutama dalam } \\
\text { hal kuantitas kerja. }\end{array}$ & 0,613 & 0,349 & Valid \\
\hline $\begin{array}{l}\text { Butir } \\
13\end{array}$ & $\begin{array}{l}\text { Sebagai karyawan PT. Singa Mas Pandaan selalu } \\
\text { menyelesaikan tugas dengan waktu yang telah ditentukan } \\
\text { perusahaan. }\end{array}$ & 0,697 & 0,349 & Valid \\
\hline $\begin{array}{l}\text { Butir } \\
14\end{array}$ & $\begin{array}{l}\text { PT. Singa Mas Pandaan memaksimalkan sumber daya } \\
\text { manusia yang telah dimiliki, sehingga tingkat efektifitas } \\
\text { perusahaan maksimal. }\end{array}$ & 0,579 & 0,349 & Valid \\
\hline $\begin{array}{l}\text { Butir } \\
15\end{array}$ & $\begin{array}{l}\text { Sebagai karyawan PT. Singa Mas Pandaan selalu } \\
\text { memperhatikan panduan kerja yang telah diberikan oleh } \\
\text { pimpinan atau pengawas. }\end{array}$ & 0,617 & 0,349 & Valid \\
\hline
\end{tabular}

Sumber: Diolah peneliti tahun 2018

\section{2) Hasil Uji Reliabilitas}

Pengujian uji reliabilitas ini bertujuan untuk mengukur sejauh mana konsistensi dari suatu instrumen penelitian. Suatu kuesioner dikatakan reliabel, apabila jawaban responden terhadap pertanyaan tersebut konsisten dari waktu ke waktu. Hasil uji ini akan dinyatakan dalam koefisien alpha, yang berkisar antara angka 0 s.d 1 . Semakin mendekati 1 sebuah alat ukur dikatakan semakin reliabel dan sebaliknya.

Hasil perhitungan uji reliabilitas dapat dilihat pada tabel berikut: 
Tabel 4. Hasil Perhitungan Uji Reliabilitas

\begin{tabular}{|l|c|c|c|}
\hline \multicolumn{1}{|c|}{ Variabel } & cronbach alpha & $\begin{array}{c}\text { N of } \\
\text { Items }\end{array}$ & Keterangan \\
\hline Motivasi X1 &, 811 & 5 & Reliabel \\
Lingkungan kerja X2 &, 783 & 5 & Reliabel \\
Kinerja karyawan Y &, 805 & 5 & Reliabel \\
\hline
\end{tabular}

Sumber: Hasil perhitungan SPSS tahun 2018

Berdasarkan tabel di atas hasil dari uji reliabilitas dengan menggunakan perhitungan dari program SPSS dapat dilihat pada kolom nilai cronbach's alpha untuk variabel motivasi sebesar 0,811 yang merupakan penilaian alpha dikatakan reabilitas baik. Sedangkan nilai cronbach's alpha untuk variabel lingkungan kerja sebesar 0,783 . Untuk variabel terikat dalam penelitian ini yaitu kinerja karyawan sebesar 0,805. Maka dapat disimpulkan bahwa seluruh variabel pada penelitian ini dinyatakan reliabel.

\section{3) Hasil Analisis Regresi Linier Berganda}

Regresi berganda adalah metode analisis yang tepat ketika penelitian melibatkan satu variabel terikat yang diperkirakan berhubungan dengan satu atau lebih variabel bebas. Tujuan analisis regresi linier berganda adalah untuk memperkirakan perubahan respon pada variabel terikat terhadap variabel bebas.

Penelitian ini peneliti menggunakan analisis regresi linier berganda dengan bantuan program SPSS, maka hasil perhitungannya dapat dilihat pada tabel berikut:

Tabel 5. Koefisien Regresi Linier Berganda

\begin{tabular}{|c|c|c|c|c|c|c|}
\hline \multirow{2}{*}{\multicolumn{2}{|c|}{ Model }} & \multicolumn{2}{|c|}{$\begin{array}{l}\text { Unstandardized } \\
\text { Coefficients }\end{array}$} & \multirow{2}{*}{$\begin{array}{c}\text { Standardized } \\
\text { Coefficients }\end{array}$} & \multirow[t]{2}{*}{$\mathrm{t}$} & \multirow[t]{2}{*}{ Sig. } \\
\hline & & B & Std. Error & & & \\
\hline & (Constant) & , 040 & ,032 & & ,025 & ,002 \\
\hline \multirow[t]{2}{*}{1} & motivasi & 181 & 119 & 149 & 1,520 & ,001 \\
\hline & lingkungan kerja & 817 & 094 & 829 & 8,675 & 000 \\
\hline
\end{tabular}

a. Dependent Variable: kinerja karyawan

Sumber: Hasil perhitungan SPSS tahun 2018 
Berdasarkan hasil perhitungan regresi linier berganda pada tabel di atas dapat diketahui persamaan regresinya sebagai berikut:

$$
Y=0,040+0,181 \times 1+0,817 \times 2+0,032
$$

Dari persamaan regresi tersebut dijelaskan sebagai berikut:

1. Nilai konstanta sebesar 0,040. Artinya konstanta bernilai positif pada hasil perhitungan regresi linier di atas menunjukkan bahwa adanya pengaruh positif dari variabel bebas yaitu motivasi dan lingkungan kerja, jika variabel bebas nilainya adalah 0 . Maka variabel terikat penelitian yaitu kinerja karyawan nilainya akan mengalami kenaikan sebesar 0,040.

2. Nilai persamaan regresi linier berganda pada variabel motivasi (X1) sebesar 0,181 artinya jika variabel lainnya tetap dan variabel motivasi mengalami kenaikan sebesar $1 \%$, maka nilai variabel terikat mengalami kenaikan sebesar 0,181. Dari perhitungan di atas menunjukkan bahwa nilai koefisien bernilai positif artinya terjadi hubungan positif antara variabel motivasi dengan variabel kinerja karyawan, semakin besar nilai pengaruh motivasi maka semakin besar peningkatan kinerja karyawan pada PT. Singa Mas Pandaan.

3. Nilai persamaan regresi linier berganda pada variabel lingkungan kerja (X2) sebesar 0,817 artinya jika variabel lainnya tetap dan variabel lingkungan kerja mengalami kenaikan sebesar $1 \%$, maka nilai variabel terikat mengalami kenaikan sebesar 0,817. Dari perhitungan di atas menunjukkan bahwa nilai koefisien bernilai positif artinya terjadi hubungan positif antara variabel lingkungan kerja dengan variabel kinerja karyawan, semakin besar nilai pengaruh lingkungan kerja maka semakin besar peningkatan kinerja karyawan pada PT. Singa Mas Pandaan.

4. Dalam perhitungan koefisien regresi linier berganda terdapat nilai epsilon (pengaruh dari faktor lain) yaitu sebesar 0,032. Artinya seluruh variabel yang dihitung dalam menggunakan program SPSS memiliki tingkat variabel pengganggu sebesar 0,032 .

Dari pembahasan di atas peneliti menyimpulkan bahwa variabel terikat penelitian yaitu kinerja karyawan pada PT. Singa Mas Pandaan dipengaruhi oleh semua varibel bebas yaitu motivasi dan lingkungan kerja. Dimana setiap kenaikan yang terjadi pada variabel bebas (independent) akan diikuti oleh kenaikan variabel terikat (dependent).

\section{4) Hasil Uji Asumsi Klasik}

\section{a. Hasil Uji Normalitas}

Uji normalitas bertujuan untuk mengetahui apakah varibelvariabel penelitian memiliki distribusi normal atau tidak. Berdasarkan gambar plot terlihat data menyebar di sekitar garis diagonal dan mengikuti arah garis diagonal. Maka dapat disimpulkan data terdistribusi secara normal. 


\section{b. Hasil Uji Multikolinieritas}

Uji multikolinieritas bertujuan untuk mengetahui apakah ada korelasi di antara variabel bebas (independent). Jika antar variabel independen saling berkorelasi maka variabel-variabel ini tidak ortogonal sehingga tidak bisa diuji menggunakan model regresi. Hasil perhitungan uji multikolinearitas dapat dilihat pada tabel berikut:

\section{Tabel 6. Hasil Uji Multikolinieritas}

\begin{tabular}{|l|r|r|}
\hline \multirow{2}{*}{ Model } & \multicolumn{2}{|c|}{ Collinearity Statistics } \\
\cline { 2 - 3 } & Tolerance & \multicolumn{1}{c|}{ VIF } \\
\hline (Constant) & & \\
Motivasi &, 572 & 4,582 \\
lingkungan kerja &, 368 & 2,256 \\
\hline
\end{tabular}

Sumber: Hasil perhitungan SPSS tahun 2018

Berdasarkan hasil perhitungan pada tabel di atas menunjukan bahwa nilai pada kolom tolerance dan nilai VIF pada semua variabel bebas yaitu bukti fisik, kehandalan, daya tanggap, jaminan dan perhatian berada di atas 0,01 dan nilai VIF masing-masing di bawah 10. Maka dapat dikatakan berarti data terbebas dari multikolineritas.

\section{c. Hasil Uji Heteroskedastisitas}

Uji heteroskedastisitas bertujuan mengetahui apakah dalam model regresi terjadi ketidaksamaan varian dari residual satu pengamatan ke pengamatan yang lain. Hasil analisis uji heteroskedastisitas dapat dilihat pada gambar berikut:

Scatterplot

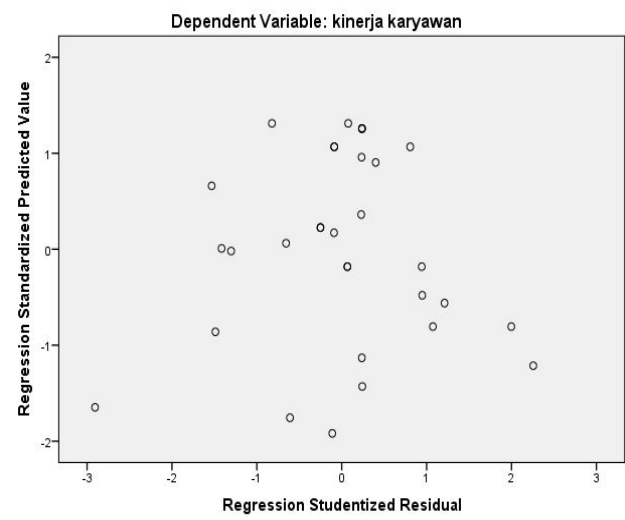

Gambar 2

Grafik Scatterplot Uji Heteroskedastisitas

Sumber: Data diolah peneliti tahun 2018 
Berdasarkan hasil dari scatter plot pada gambar di atas menunjukkan bahwa plot yang terbentuk tidak memiliki pola yang jelas, serta titik-titik menyebar di atas dan di bawah angka 0 pada sumbu $Y$, maka dapat dikatakan tidak terjadi heteroskedastisitas.

\section{d. Hasil Uji Autokorelasi}

Uji autokorelasi bertujuan untuk menguji apakah dalam model regresi linier berganda ada korelasi antara kesalahan pengganggu pada periode $t$ dengan kesalahan pengganggu pada periode $\mathrm{t}-1$ (sebelumnya). Autokorelasi dapat diketahui melalui uji Durbin-Watson (DW test). Berikut hasil pengujian autokorelasi yang disajikan pada tabel di bawah ini:

Tabel 7. Hasil Perhitungan Uji Autokorelasi

\begin{tabular}{|l|r|}
\hline Model & \multicolumn{1}{|c|}{$\begin{array}{l}\text { Durbin- } \\
\text { Watson }\end{array}$} \\
\hline 1 & 1,8038 \\
\hline
\end{tabular}

Sumber: Data diolah peneliti tahun 2018

Berdasarkan hasil perhitungan pada tabel di atas didapat nilai DW sebesar 1,8038. Nilai ini akan dibandingkan dengan nilai tabel dengan menggunakan nilai signifikansi sebesar $5 \%$ atau 0,05.

Untuk jumlah data sampel penelitian sebanyak 32 responden, maka nilai $\mathrm{dL}$ sebesar 1,1092 dan dU sebesar 1,8187. Karena nilai dL $(1,1092)<$ nilai dW $(1,8038)$ dan < nilai dU $(1,8187)$. Maka dapat disimpulkan bahwa tidak terdapat autokorelasi pada penelitian ini.

\section{5) Hasil Uji Hipotesis}

\section{a. Hasil Uji Pengaruh Simultan (Uji F)}

Uji simultan (uji F) bertujuan untuk mengetahui pengaruh secara bersama-sama (simultan) dari variabel bebas terhadap variabel terikat. Perhitungan uji simultan dilakukan dengan menggunakan tabel anova sebagai hasil pengolahan data dengan menggunakan program SPSS dapat dilihat sebagai berikut: 
Tabel 8. Hasil Uji Simultan

\section{ANOVA $^{a}$}

\begin{tabular}{|rl|r|r|r|r|r|}
\hline & Model & \multicolumn{1}{c|}{$\begin{array}{c}\text { Sum of } \\
\text { Squares }\end{array}$} & df & Mean Square & F & Sig. \\
\hline \multirow{2}{*}{1} & Regression & 346,414 & 2 & 173,207 & 126,990 &, $000^{\mathrm{b}}$ \\
& Residual & 39,554 & 29 & 1,364 & & \\
& Total & 385,969 & 31 & & & \\
\hline
\end{tabular}

a. Dependent Variable: kinerja karyawan

b. Predictors: (Constant), lingkungan kerja, motivasi

Sumber: Hasil perhitungan SPSS tahun 2018

Berdasarkan tabel di atas hasil perhitungan uji simultan menunjukkan bahwa nilai $\mathrm{F}$ hitung sebesar 126,990 . Sedangkan dilihat dari taraf signifikan sebesar 0,000. Artinya nilai signifikansi uji simultan sebesar 0,000 lebih kecil dari 0,05 maka dapat disimpulkan bahwa adanya pengaruh signifikan secara bersama-sama antara variabel bebas (independent) yaitu motivasi dan lingkungan kerja terhadap variabel kinerja karyawan pada PT. Singa Mas Pandaan.

\section{b. Hasil Uji Pengaruh Parsial ( Uji t)}

Uji t bertujuan untuk mengetahui besarnya pengaruh masingmasing variabel bebas secara parsial terhadap variabel terikat. Hasil perhitungan uji parsial adalah sebagai berikut:

\section{Tabel 9. Hasil Perhitungan Uji Parsial}

\begin{tabular}{|ll|r|r|}
\hline \multicolumn{2}{|l|}{ Model } & \multicolumn{1}{c|}{$\mathrm{t}$} & \multicolumn{1}{c|}{ Sig. } \\
\hline \multicolumn{2}{|c|}{ (Constant) } &, 025 &, 002 \\
\cline { 2 - 4 } & Motivasi & 1,520 &, 001 \\
& Lingkungan Kerja & 8,675 &, 000 \\
\hline
\end{tabular}

Sumber: Hasil perhitungan SPSS tahun 2018

Hasil perhitungan uji secara parsial berdasarkan tabel di atas dengan menggunakan program SPSS dapat dijelaskan sebagai berikut: 
1. Berdasarkan tabel di atas hasil perhitungan secara parsial menunjukkan nilai $\mathrm{t}$ hitung pada variabel motivasi sebesar 1,520 dengan tingkat signifikansi 0,001. Artinya bahwa variabel motivasi mempunyai pengaruh positif dan signifikan terhadap variabel kinerja karyawan pada PT. Singa Mas Pandaan.

2. Berdasarkan tabel di atas hasil perhitungan secara parsial menunjukkan nilai t hitung pada variabel lingkungan kerja sebesar 8,675 dengan tingkat signifikansi 0,000. Artinya bahwa variabel lingkungan kerja mempunyai pengaruh positif dan signifikan terhadap variabel kinerja karyawan pada PT. Singa Mas Pandaan.

Berdasarkan hasil di atas dapat disimpulkan bahwa masing-masing dari varibael bebas (independent) berpengaruh positif dan signifikan terhadap variabel terikat (dependent). Pada uji parsial ini terdapat variabel yang berpengaruh paling dominan yaitu lingkungan kerja dengan nilai signifikan lebih kecil $(0,000)$ dari variabel motivasi yaitu 0,001 . Sehingga dapat disimpulkan bahwa variabel lingkungan kerja merupakan variabel yang berpengaruh paling dominan terhadap variabel kinerja karyawan pada PT. Singa Mas Pandaan.

\section{6) Pembahasan Penelitian}

a. Motivasi dan Lingkungan Kerja Berpengaruh Secara Simultan Terhadap Kinerja Karyawan PT. Singa Mas Pandaan

Berdasarkan tabel di atas hasil perhitungan uji simultan menunjukkan bahwa nilai $\mathrm{F}$ hitung sebesar 126,990. Sedangkan dilihat dari taraf signifikan sebesar 0,000 . Artinya nilai signifikansi uji simultan sebesar 0,000 lebih kecil dari 0,05 maka dapat disimpulkan bahwa adanya pengaruh signifikan secara bersama-sama antara variabel bebas (independent) yaitu motivasi dan lingkungan kerja terhadap variabel kinerja karyawan pada PT. Singa Mas Pandaan.

b. Motivasi dan Lingkungan Kerja Berpengaruh Secara Parsial Terhadap Kinerja Karyawan PT. Singa Mas Pandaan

Pembahasan hasil perhitungan uji secara parsial berdasarkan tabel 9 di atas dengan menggunakan program SPSS dapat dijelaskan sebagai berikut:

1) Berdasarkan tabel 9 hasil perhitungan secara parsial menunjukkan nilai t hitung pada variabel motivasi sebesar 1,520 dengan tingkat signifikansi 0,001. Artinya bahwa variabel motivasi mempunyai pengaruh positif dan signifikan terhadap variabel kinerja karyawan pada PT. Singa Mas Pandaan. 
2) Berdasarkan tabel 9 hasil perhitungan secara parsial menunjukkan nilai t hitung pada variabel lingkungan kerja sebesar 8,675 dengan tingkat signifikansi 0,000. Artinya bahwa variabel lingkungan kerja mempunyai pengaruh positif dan signifikan terhadap variabel kinerja karyawan pada PT. Singa Mas Pandaan.

Kesimpulan dari hasil perhitungan secara parsial di atas adalah masing-masing dari varibael bebas (independent) yaitu motivasi dan lingkungan kerja berpengaruh positif dan signifikan terhadap variabel terikat (dependent) yaitu kinerja karyawan.

\section{c. Pengaruh Variabel Paling Dominan Antara Motivasi atau Lingkungan Kerja Terhadap Kinerja Karyawan PT. Singa Mas Pandaan}

Berdasarkan pada hasil perhitungan uji parsial dapat diketahui variabel yang mempunyai pengaruh paling dominan yaitu lingkungan kerja dengan nilai signifikan lebih kecil $(0,000)$ dari variabel motivasi yaitu 0,001 . Sehingga dapat disimpulkan bahwa variabel lingkungan kerja merupakan variabel yang berpengaruh paling dominan terhadap variabel kinerja karyawan pada PT. Singa Mas Pandaan.

\section{SIMPULAN}

Penelitian yang berjudul "Pengaruh Motivasi Dan Lingkungan Kerja Terhadap Kinerja Karyawan Bagian Packing Produk Minuman (Studi Kasus Pada PT. Singa Mas Pandaan)", dapat ditarik beberapa kesimpulan sebagai berikut:

1. Terdapat adanya pengaruh secara simultan (bersama-sama) dari variabel motivasi dan lingkungan kerja terhadap variabel kinerja karyawan. Hal tersebut dapat dilihat pada hasil perhitungan secara simultan menunjukkan bahwa nilai $\mathrm{F}$ hitung sebesar 126,990 . Sedangkan dilihat dari taraf signifikan sebesar 0,000. Artinya nilai signifikansi uji simultan sebesar 0,000 lebih kecil dari 0,05, maka dapat disimpulkan bahwa adanya pengaruh signifikan secara bersama-sama antara variabel bebas (independent) yaitu motivasi dan lingkungan kerja terhadap variabel kinerja karyawan pada PT. Singa Mas Pandaan.

2. Berdasarkan hasil perhitungan secara parsial yaitu:

a.Secara parsial menunjukkan nilai t hitung pada variabel motivasi sebesar 1,520 dengan tingkat signifikansi 0,001 . Artinya bahwa variabel motivasi mempunyai pengaruh positif dan signifikan terhadap variabel kinerja karyawan pada PT. Singa Mas Pandaan. Hal tersebut dapat dilihat dari instrumen motivasi yang berpangaruh positif dan signifikan terhadap kinerja karyawan PT. Singa Mas Pandaan. 
b. Secara parsial menunjukkan nilai t hitung pada variabel lingkungan kerja sebesar 8,675 dengan tingkat signifikansi 0,000. Artinya bahwa variabel lingkungan kerja mempunyai pengaruh positif dan signifikan terhadap variabel kinerja karyawan pada PT. Singa Mas Pandaan. Hal tersebut dapat dilihat dari instrumen lingkungan kerja yang berpangaruh positif dan signifikan terhadap kinerja karyawan PT. Singa Mas Pandaan.

3. Berdasarkan pada hasil perhitungan uji parsial dapat diketahui variabel yang mempunyai pengaruh paling dominan yaitu lingkungan kerja dengan nilai signifikan lebih kecil $(0,000)$ dari variabel motivasi yaitu 0,001 . Sehingga dapat disimpulkan bahwa variabel lingkungan kerja merupakan variabel yang berpengaruh paling dominan terhadap variabel kinerja karyawan pada PT. Singa Mas Pandaan.

\section{SARAN}

Berdasarkan data yang telah peneliti analisis dan kesimpulan yang telah dibuat, maka peneliti memberikan saran yang berkaitan dengan pengaruh motivasi dan lingkungan kerja terhadap kinerja karyawan.

Hasil penelitian pada pada PT. Singa Mas Pandaan dapat diketahui bahwa variabel motivasi masih rendah terhadap kinerja karyawan, hal ini menunjukkan banyak terjadi dari faktor-faktor yang mengacu pada instrumen penelitian. Mengingat pentingnya motivasi karyawan terhadap kinerja perusahaan PT. Singa Mas Pandaan. Diharapkan lebih ditingkatkan kembali faktor-faktor yang ada kaitannya terhadap motivasi karyawan, sehingga jika hal ini diterapkan dengan baik akan terjadi suasana kerja yang lebih maksimal maka akan berpengaruh positif terhadap kinerja karyawan PT. Singa Mas Pandaan.

Sedangkan lingkungan kerja terhadap kinerja karyawan PT. Singa Mas Pandaan sudah maksimal, artinya lingkungan kerja berpengaruh paling dominan terhadap kinerja karyawan PT. Singa Mas Pandaan.

\section{DAFTAR PUSTAKA}

Abdullah, M. 2014. Manajemen dan Evaluasi Kinerja Karyawan. Yogyakarta: Aswaja Pressindo.

Alisah, Evawati \& Eko Prasetyo Darmawan. 2007. Filsafat Dunia Matematika. Jakarta: Prestasi Pustakaraya.

Bangun, Wilson. 2012. Manajemen Sumber Daya Manusia. Jakarta: Erlangga.

Bernardin, H. John, \& Joyce E.A Russel. 2009. Human resource management (An Experimental Approach International Edition), Singapore : Mc.Graw Hill Inc. 
Da Silva Pereira, Belarmino. 2013. Pengaruh Kompetensi dan Kompensasi. Perawat Terhadap Kinerja Perawat di Hospital Nacional Guido Valadares Timor Leste. Tesis Manajemen. Bandung: Universitas Padjajaran.

Eko, Suparno, Widodo. 2015. Manajemen Pengembangan Sumber Daya. Manusia. Yogyakarta: Pustaka Pelajar.

Ghozali, Imam. 2012. Aplikasi Analisis Multivariate dengan Program IBM SPSS. Yogyakarta: Universitas Diponegoro.

Ghozali, Imam. 2016. Aplikasi Analisis Multivariate Dengan Program IBM SPSS 23. Semarang: Badan Penerbit Universitas Diponegoro.

Hasibuan, Malayu S.P. 2011. Manajemen: Dasar, Pengertian, dan Masalah. Jakarta: PT Aksara.

Hasibuan, Malayu. S.P. 2014. Manajemen Sumber Daya Manusia. Edisi Revisi. Jakarta: Bumi Aksara.

Mangkunegara, Prabu, Anwar, A.A. 2012. Manajemen Sumber Daya Manusia. Bandung: PT. Remaja Rosdakarya.

Mangkunegara, Prabu, Anwar, A.A. 2013. Manajemen Sumber Daya Manusia. Bandung: PT. Remaja Rosdakarya.

Marwansyah. 2010. Manajemen Sumber Daya Manusia. Bandung: Alfabeta.

Mekel Peggy, Sahlan Nurul Ikhsan, Trang Irvan. 2015. Pengaruh Lingkungan Kerja, Kepuasan Kerja Dan Kompensasi Terhadap Kinerja Karyawan Pada PT. Bank Sulut Cabang Airmadidi. Manado. Jurnal EMBA. Vol.3 No.1:52-62. ISSN 2303-1174.

Moeheriono. 2012. Pengukuran Kinerja Berbasis Kompetensi. Jakarta: Raja. Grafindo Persada.

Moorhead dan Griffin. 2013. Perilaku Organisasi. Jakarta: Salemba Empat.

Nugroho, B., \& Satrio, B. 2016. Pengaruh Motivasi dan Lingkungan Kerja Terhadap Kinerja Karyawan Auto 2000 Sungkono Surabaya. Jurnal IImu dan Riset Manajemen Vol 5. No 4.

Noor, Juliansyah. 2014. Metodologi Penelitian. Jakarta: Kencana..

Rosa, Hendri. 2015. Pengaruh Lingkungan Kerja dan Pelatihan Terhadap Kinerja Karyawan PTPN VI Unit Ophir Sariak. Pasaman: e-Jurnal Apresiasi Ekonomi Volume 3, Nomor 2, Mei 2015 : 187 - 197.

Rahmawati, Nela Pima dkk. 2014. Pengaruh Lingkungan Kerja Terhadap Kinerja Karyawan (Studi pada Karyawan Kantor Pelayanan Pajak Pratama Malang Utara). Malang: Jurnal Administrasi Bisnis (JAB)| Vol. 8 No. 2.

Robbins, S.P dan Judge T.A. 2015. Perilaku Organisasi. Jakarta: Salemba Empat.

Sahanggamu, Patricia M. dan Silvya L. Mandey. 2014. Pengaruh Pelatihan Kerja, Motivasi dan Disiplin Kerja terhadap Kinerja Karyawan pada PT Bank Perkreditan Rakyat Dana Raya. Manado: Jurnal Emba. 
Sandy, Muhammad. 2015. Karakteristik Pekerjaan dan Kinerja Dosen Luar Biasa UIN Sunan Gunung Djati. Komitmen Organisasi Sebagai Variabel Moderating. Bandung: Universitas Widyatama.

Sedarmayanti. 2013. Manajemen Sumber Daya Manusia, Reformasi Birokrasi dan Manajemen Pegawai Negeri Sipil. Bandung: Refika Aditama.

Sekaran, Uma. 2000. Metodologi Penelitian. Yogyakarta: Salemba Empat.

Sugiyono. 2003. Metode Penelitian Bisnis. Edisi 1. Bandung: Alfabeta.

Sugiyono. 2013 Metode Penelitian Kuantitatif Kualitatif dan R\&D. Bandung: Alfabeta.

Sugiyono. 2014. Metode Penelitian Kuantitatif Kualitatif dan R\&D. Bandung : Alfabeta.

Sugiyono. 2011. Metode Penelitian Kuantitatif, Kualitatif dan R\&D. Bandung: Afabeta

Sugiyono. 2017. Metode Penelitian Kuantitatif, Kualitatif dan R\&D. Bandung: Alfabet.

Sugiyono. 2010. Metode Penelitian Pendidikan Pendekatan Kuantitatif, kualitatif, dan R\&D. Bandung: Alfabeta.

Sugiyono. 2012. Metode Penelitian Kuantitatif Kualitatif dan R\&D. Bandung: Alfabeta.

Sugiyono. 2009. Metode Penelitian Kuantitatif, Kualitatif dan R\&D. Bandung : Alfabeta.

Sunyoto, Danang. 2016. Manajemen dan Pengembangan Sumber Daya Manusia

(Cetakan Pertama). Yogyakarta: CAPS (Center for Academic

Publishing Service).

Torang, Syamsir. 2013. Organisasi dan Manajemen (Perilaku, Struktur, Budaya. \& Perubahan Organisasi. Bandung: Alfabeta.

Uno, Hamzah. B. 2010. Perencanaan Pembelajaran. Jakarta: Bumi Aksara.

Wayne, Mondy R. 2008. Manajemen Sumber Daya Manusia. Jakarta: Erlangga.

Zameer, Hashim, Shehzad Ali, Waqar Nisar dan Muhammad Amir. 2014. The Impact of the Motivation on the Employee's Performance in Beverage Industry of Pakistan. International Journal of Academic Research in Accounting, Finance and Management Sciences Vol. 4, No.1. p. 293-298. 